\title{
A man who has made his Marks on science
}

A scientific symposium honoring the contribution of Paul A. Marks to science in New York City was held at Columbia University Medical Center in early September. Both Columbia University and Memorial SloanKettering Cancer Center (MSKCC) sponsored the symposium, which honored the man who, as vice president for medical sciences at Columbia University from 1970 to 1980 and as president and chief executive officer of MSKCC from 1980 to 1999, helped shape the institutions into what they are today. learn firsthand the respect Marks has garnered for his work in the laboratory, where he has been the lead investigator in the development of the first inhibitor of histone deacetylases (HDACs), suberoylanilide hydroxamic acid (SAHA), for use as an anticancer drug. Lee Goldman, the current vice president for health and biomedical sciences at Columbia, summed up the many plaudits awarded Marks by the distinguished speakers (including eight Nobel laureates) when he said, "Paul is the epitome of the physician-scientist."

The JCI took the opportunity to speak with Marks about his experiences as a scientist and his plans for the future.

JCI: Are you still actively engaged in science?

Marks: Science is too big a passion in my life for me to want to retire. So, as long as I am able and have the funding to do so I will definitely stay in science. Currently my lab is looking at the mechanisms underlying the anticancer effects of SAHA to try and better understand why it is such a good anticancer
The symposium was an opportunity to

agent with low toxicity. In particular, we are looking at the pathways of cell death that SAHA initiates, at the expression of HDACs in cancer tissues, and the biological activity of HDACs and HDAC inhibitors in normal and cancerous cells.

JCI: How did you become interested in cancer biology?

Marks: Well, more than 30 years ago, we were studying genetically determined defects in red blood cells, such as those that cause glucose-6-phosphate dehydrogenase deficiency hemolytic anemia and thalassemia. But then in 1971 I read a really interesting paper in PNAS [Proceedings of the National Academy of Sciences of the United States of America] by Charlotte Friend. She was looking at ways to determine whether superinfection of leukemic cells with Friend virus using the solvent DMSO was possible. In this paper she showed that DMSO stimulates the differentiation of Friend virus-induced erythroleukemic cells to red blood cells. This mostly interested me because, given our interest in thalassemia, I wanted to understand how DMSO induced the expression of the globin genes, but it also caught my eye because it meant that destroying cancer cells was not the only way to stop them being cancerous. So, we began looking for other chemicals that could induce the differentiation of Friend virus-induced erythroleukemic cells. The first studies, performed with the Merck library of compounds, drew a blank and so I approached my friend Ronald Breslow, who was a chemist at Columbia University. And there started a 30-year collaboration that

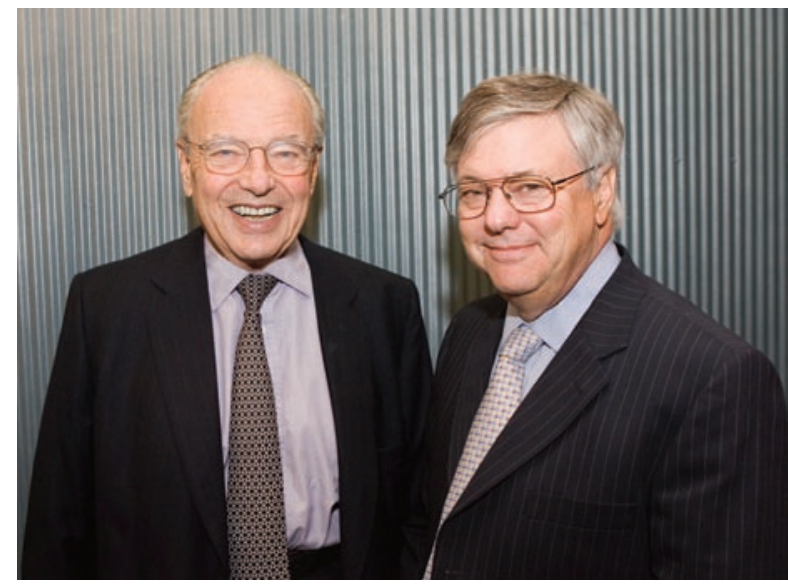

Paul A. Marks (left) and Michael Brown (right) talk things over at the symposium held in Marks's honor. Image credit: Charles Manley, Columbia University. has resulted in the generation of SAHA and hopefully a treatment for cancer.

JCI: What are the biggest changes that have occurred since you began studying the differentiation of erythroleukemic cells?

Marks: The biggest thing that has changed is that technology has advanced enormously. So much so that our understanding of the nature of cancer is much better. But I think that the most important thing to remember as we go forward is that cancer is an extremely complex disease and not a single entity. One thing that highlights this complexity is that if we look at the effects of SAHA on prostate cancer cells from different individuals we see very different effects.

JCI: Given your many accomplishments highlighted throughout the symposium, what do you consider your greatest scientific accomplishment?

Marks: The discovery and development of SAHA as an effective anticancer therapeutic, which we hope will soon be the first HDAC inhibitor to be approved by the FDA for clinical use. But more importantly, I'm extremely proud of the fact that this was a collaboration that spanned three decades and that all of the work, right up until the phase II clinical trials, was undertaken in an academic setting.

JCI: On the flip side, your time spent in positions of administrative responsibility - as vice president for medical sciences at Columbia University and as president and chief executive officer of MSKCC - is also highly regarded. What satisfaction did you gain from your time in these positions?

Marks: It is definitely very different from being in the lab, but I derived enormous pleasure from recruiting excellent scientists and clinicians. This gave me the satisfaction not only of building and improving great institutions but also the chance to work with amazingly talented people.

JCI: Given your nose - as Joseph Goldstein and Michael Brown illustrated at the symposium with René Magritte's La bonne aventure - for recruiting highly talented individuals, what advice did you give your son Andrew when he became editor-inchief of the JCI in 2002, a position you held from 1967 to 1971 ?

Marks: I told him candidly that although it is a tremendous amount of work, it is a terrific experience for someone who loves science.

\section{Karen Honey}

